\title{
Program Campus Social Responsibility (CSR) One To One UM Surabaya Sebagai Upaya Menekan Angka Anak Putus Sekolah di Kota Surabaya \\ Aristiana Prihatining Rahayu ${ }^{1^{*}}$, Agoes Poerwanto ${ }^{2}$, gatmain $^{3}$ \\ 1,2,3 Universitas Muhammadiyah Surabaya \\ Email: aprahayu123@gmail.com¹, aguspoerwanto@yahoo.com², dirjopenewu@gmail.com ${ }^{3}$ \\ Corresponding author: : aprahayu123@gmail.com ${ }^{1}$
}

\begin{abstract}
ABSTRAK
Pesatnya jumlah dan sebaran permasalahan sosial kota Surabaya, belum sebanding dengan daya jangkau, kapasitas, dan, kemampuan pelayanan sosial yang dilakukan pemerintah. Kewajiban pemerintah dalam memenuhi hak-hak dasar warganya belum dapat terlaksanakan secara maksimal, termasuk dalam persoalan pendidikan. Untuk itu, pemerintah kota Surabaya melalui Dinas Sosial bekerja sama dengan perguruan tinggi negeri dan swasta yang ada di kota Surabaya untuk memberikan pendampingan pendidikan kepada anak dari keluarga penyandang masalah kesejahteraan sosial (miskin), yang rentan atau putus sekolah melalui program Campus Social Responsibility (CSR) One to One. Dalam proses pelaksanaannya, mahasiswa diterjunkan untuk melakukan berbagai program pendampingan yang mengarah pada tujuan besar yakni menekan angka anak rawan dan putus sekolah. Sasaran dari program adalah anak dari keluarga penyandang masalah kesejahteraan sosial (PMKS) yang putus atau rentan putus sekolah, yang terdata Dinas Sosial Kota Surabaya. Luarannya adalah terbangunnya motivasi adik damping untuk tetap semangat sekolah, dan mengembalikan mereka yang putus sekolah untuk kembali ke bangku sekolah. Metode pelaksanaannya_koordinasi antara dinas sosial dan PTN/PTS di Kota Surabaya, sosialisasi program ke mahasiswa, perekrutan tim CSR, pelaksanaan pendampingan dan evaluasi. Indikator program CSR ini adalah mahasiswa mampu mengembalikan adik damping mereka yang rentan maupun putus sekolah, untuk kembali dan makin termotivasi bersekolah.
\end{abstract}

kata kunci : campus social responsibility, dinas sosial, mahasiswa

\section{One To One UM Surabaya Campus Social Responsibility (CSR) Program as an Effort to Reduce the Number of Children Dropping Out of School in the City of Surabaya}

\begin{abstract}
The rapid number and distribution of social problems in the city of Surabaya is not yet comparable to the reach, capacity and ability of social services provided by the government. The government's obligation to fulfill the basic rights of its citizens has not been maximally implemented, including in matters of education. For this reason, the Surabaya city government through the Social Service collaborates with public and private universities in the city of Surabaya to provide educational assistance to children from families with social welfare problems (poor), who are vulnerable or drop out of school through the One to One Campus Social Responsibility (CSR) program. In the implementation process, students are deployed to carry out various mentoring programs that aim at the big goal of reducing the number of vulnerable children and dropping out of school. The target of the program is children from families with social welfare problems (PMKS) who drop out or are prone to dropping out of school, which is recorded by the Surabaya City Social Service. The result
\end{abstract}


is the awakening of the motivation of the assistants to keep up the spirit of school, and to return those who drop out of school to return to school. The method of implementation is coordination between social services and PTN / PTS in the city of Surabaya, socialization of the program to students, recruitment of CSR teams, implementation of mentoring and evaluation. The indicator of this CSR program is that students are able to return their siblings who are vulnerable or drop out of school, to return and be more motivated to go to school.

keywords: campus social responsibility, social service, student

\section{PENDAHULUAN}

Problem masyarakat miskin kota, adalah persoalan yang tidak bisa dielakkan dtengah proses pembangunan di perkotaan. Masyarakat miskin yang ada di perkotaan, adalah mereka yang termarginalkan dan tergerus oleh sengitnya persaingan hidup yang berat dalam memperoleh kesejahteraan ekonomi maupun kesejahteraan sosial. Kelompok masyarakat ini, rata-rata berasal dari kelompok masyarakat dengan pendidikan rendah. Kondisi ini menyebabkan mereka tidak mampu bersaing dalam mendapatkan pekerjaan dengan hasil (gaji/upah) yang mampu mencukupi kebutuhan keluarga. Dampaknya pada kondisi pendidikan anak-anak dari keluarga pra sejahtera tersebut adalah mereka sangat rentan atau bahkan putus sekolah. Studi yang dilakukan Kuntoro dkk. (1996) di Propinsi Jawa Timur menemukan faktor utama yang menyebabkan anak-anak terpaksa tidak melanjutkan sekolah adalah karena orang tua mereka kesulitan membiayai sekolah anak-anaknya. Kesimpulan Kuntoro ini sama dengan hasil studi BPS 1994 “ Indikator Kesejahteraan Anak", di kalangan penduduk berumur 5-29 tahun yang putus sekolah, alasan yang paling dominan adalah tidak mempunyai biaya.

Meski saat ini, terutama di sekolah-sekolah negeri, pemerintah telah menggratiskan sebagian biaya sekolah, namun bagi sebagian orang tua, pendidikan dianggap masih membebani karena mereka harus mengeluarkan uang untuk pos lainnya _seperti uang saku, uang transport ke sekolah.

Selain karena faktor ekonomi, anak-anak yang rentan dan putus sekolah, juga dipicu oleh faktorfaktor lain_misalnya minimnya motivasi dari diri sendiri dan orang tua, problem dalam keluarga, lingkungan pergaulan yang kurang baik, kemiskinan, serta kondisi lingkungan sekolah yang kurang bersahabat. Orang tua yang tidak sekolah, biasanya akan mengalami kesulitan membantu anaknya belajar, tidak mampu membentu anaknya belajar, tidak mampu membantu memecahkan persoalan di sekolah yang dihadapi anak.

Motivasi orang tua terkait pendidikan anak sangat diperlukan. Idealnya, orang tua senantiasa harus memberikan dorongan, semangat, dan perhatian yang besar untuk pendidikan anak-anak mereka. Namun pada kenyataanya, hal tersebut tidak terjadi pada semua 
anak. Kesadaran orang tua akan pentingnya pendidikan, di kalangan masyarakat miskin belum berkembangn dengan maksimal. Tentu sangat sulit bagi anak yang tumbuh dan berkembangan dalam lingkungan yang tidak memiliki kesadaran akan pentingnya pendidikan, serta bergaul dalam lingkungan pergaulan yang temantemannya tidak lagi bersekolah atau sering membolos sekolah, akan sulit bisa bertahan untuk bisa bersemangat sekolah. Apalahi di kalangan anakanak seusia 7-13 tahun, secara teoritis pengaruh peer group sangat kuat.

Dalam penelitian Bagong Suyanto terhadap dengan 150 anak terkait permasalahan anak putus sekolah, diketemukan bahwa $26,7 \%$ respoden tidak menyesal telah putus sekolah. Namun demikian, sebagian responden lainnya agak menyesal $(45,3 \%)$, menyesal $(20,7 \%)$, dan bahkan ada responden yang menyatakan sangat menyesal telah putus sekolah (7,3\%). Perasaan penyesalan karena putus sekolah lebih disadari pemikiran bahwa dengan putus sekolah mereka akan kehilangan kesempatan untuk mendapatkan pekerjaan tertentu. Terkait keinginan responden, penelitian yang dilakukan ini menemukan bahwa $38 \%$ responden menyatakan sudah tidak ingin lagi bersekolah, 45,3\% sebetulnya masih ingin melanjutkan sekolah, dan $16,7 \%$ ingin sekali melanjutkan sekolah.
Hasil studi yang dilakukan menggambarkan bahwa sebagian anak-anak yang terpaksa putus sekolah masih memiliki keinginan untuk bisa kembali bersekolah, karena mempertimbangkan masa depan. Ketidakberdayaan anak-anak melawan kondisi yang tidak mendukungnya untuk bisa terus sekolah.

Pesatnya jumlah dan sebaran permasalahan anak saat ini belum sebanding dengan daya jangkau, kapasitas dan kemampuan pelayanan sosial. Kewajiban pemerintah dalam memenuhi hak-hak dasar warganya belum dapat terlaksana secara wajar. Untuk mengurangi dampak negatif anak dari keluarga penyandang masalah kesejahteraan sosial (PMKS), pemerintah Kota Surabaya melalui Dinas Sosial berkerja sama dengan perguruan tinggi di Surabaya memberikan pendampingan kepada anak-anak dari keluarga kelompok masyarakat ini. Salah satu program yang dicetuskan adalah Campus Social Responsibility (CSR). CSR merupakan program kerjasama antara dinas sosial (Dinsos) kota Surabaya dengan kurang lebih 24 perguruan tinggi (PT) negeri maupun swasta yang ada di kota Surabaya, salah satunya adalah Universitas Muhammadiyah Surabaya dalam melakukan pendampingan kepada anak penyandang Masalah Kesejahteraan Sosial (PMKS).

Kasus anak yang rentan dan putus sekolah di Surabaya tergolong tidak sedikit. Mengingat kota ini 
menjadi rujukan masyarakat dari berbagai daerah di Indonesia untuk mengadu nasib yang sayangnya, tidak semua dari mereka terhitung berhasil dalam ekonomi. Dan hal ini berpengaruh pada tingkat kesejahteraan keluarga sekaligus pendidikan anak dalam keluarga tersebut. Selama ini data yang dimiliki pemerintah kota Surabaya (Dinas Sosial) dalam penanganan permasalahan sosial adalah data warga yang memiliki identitas kartu keluarga sebagai warga kota Sirabaya. Di luar itu, tidak sedikit masyarakat yang telah bertahuntahun dan menetap di Surabaya tidak memiliki identitas sebagai warga Surabaya. Hal ini menyebabkan terkadang kelompok masyarakat ini, tidak termasuk menjadi bagian warga yang mendapatkan akses pendampingan kesejahteraan sosial, termasuk pendidikan.

Tabel 1. Data Anak Penyandang Masalah

Kesejahteraan Sosial

\begin{tabular}{|l|l|l|l|l|l|l|}
\hline $\begin{array}{l}\text { Data Adik } \\
\text { Asuh Program } \\
\text { CSR }\end{array}$ & 2014 & 2015 & 2016 & 2017 & 2018 & 2019 \\
\hline $\begin{array}{l}\text { Jumlah adik } \\
\text { asuh }\end{array}$ & 215 & 234 & 301 & 503 & 492 & 533 \\
\hline $\begin{array}{l}\text { Jumlah yang } \\
\text { putus sekolah }\end{array}$ & 163 & 189 & 135 & 190 & 145 & 195 \\
\hline $\begin{array}{l}\text { Jumlah yang } \\
\text { rentan putus } \\
\text { sekolah }\end{array}$ & 52 & 45 & 166 & 313 & 347 & 338 \\
\hline
\end{tabular}

(Sumber: Dinas Sosial Kota Surabaya)

$$
\text { Dalam kegiatan }
$$

pendampingan di lapangan, mahasiswa sebagai kakak asuh melakukan pendampingan dengan mengunjungi adik asuhnya minimal satu kali dalam seminggu untuk memberikan motivasi supaya mau kembali bersekolah, melakukan pendampingan belajar dan memfasilitasi mengembalikan adik asuh ke sekolah dengan mencarikan sekolah sesuai dengan riwayat putus sekolahnya serta mengontrol perkembangan adik asuh agar tidak kembali putus sekolah. Selain itu dalam proses pendampingan, mahasiswa akan membantu perubahan perilaku adik asuh supaya lebih baik dan membantu penyelesaian masalah sosial dalam keluarga tersebut. Selain melakukan pendampingan kepada adik asuh tekait pendidikannya, mahasiswa yang terlibat dalam program CSR didorong untuk bisa memfasilitasi permasalahan dalam keluarga seperti: 1. Membantu pengurusan $\mathrm{KK}$ dan Akta Kelahiran adik asuh

2. Membantu mengusulkan keluarga adik asuh untuk masuk dalam kegiatan Permakanan PMKS (Penyandang Masalah Kesejahteraan Sosial) bagi adik asuh yang yatim/piatu/yatim piatu, nenek/kakeknya lansia miskin, atau ada anggota keluarga yang cacat miskin

3. Membantu pengurusan surat nikah bagi orang tua adik asuh apabila status pernikahan orang tuanya masih nikah siri diusulkan dalam program isbat nikah massal

4. Memfasilitasi apabila adik asuh ada ynag belum khitan untuk 
diusulkan dalam program sunat massal

5. Memfasilitasi rumah adik asuh yang tidak layak untuk diusulkan dalam program rehabilitasi sosial daerah kumuh

6. Apabila ada anggota keluarga yang sakit, bisa membantu menghubungi ambulance gratis Dinas Sosial untuk mengantarkan ke Rumah Sakit

Dalam program CSR, setiap perguruan tinggi yang terlibat

Tabel 2. Program Kegiatan CSR Universitas Muhammadiyah

\begin{tabular}{|l|l|l|}
\hline PROGRAM & TARGET LUARAN & $\begin{array}{l}\text { REALISASI } \\
\text { PROGRAM }\end{array}$ \\
\hline $\begin{array}{l}\text { Pendampingan } \\
\text { belajar }\end{array}$ & $\begin{array}{l}\text { 1. Adik asuh/adik damping termotivasi untuk rajin } \\
\text { belajar } \\
\text { 2. Meningkatnya prestasi akademik adik asuh }\end{array}$ & Mei - Desember 2019 \\
\hline $\begin{array}{l}\text { Pemberian beasiswa } \\
\text { untuk Adek Asuh } \\
\text { yang berprestasi }\end{array}$ & $\begin{array}{l}\text { 1.Terbangunnya hubungan sosial yang makin erat } \\
\text { antara UMS, LAZ, Donatur dan masyarakat dhuafa } \\
\text { 2.Adek asuh makin termotivasi untk selalu } \\
\text { berprestasi }\end{array}$ & Mei-Juni 2019 \\
\hline $\begin{array}{l}\text { Pengembangan Minat } \\
\text { dan Bakat Adek Asuh }\end{array}$ & $\begin{array}{l}\text { 1.Adek asuh memiliki kemampuan keahlian di luar } \\
\text { bidang akademik yang mampu menunjang } \\
\text { prestasinya dan meningkatkan rasa percaya dirinya. }\end{array}$ & Mei 2019 s/d Desember \\
\hline $\begin{array}{l}\text { Sedekah Buku } \\
\text { 1.Tersediannya buku pelajaran bagi adek asuh. } \\
\text { 2. Tersedianya buku bacaan fiksi maupun non fiksi } \\
\text { bagi adik asuh. }\end{array}$ & Mei s/d Juni 2019 \\
\hline $\begin{array}{l}\text { FGD Pemetaan dan } \\
\text { Pemecahan Masalah }\end{array}$ & $\begin{array}{l}\text { 1.Permasalahan pendampingan yang ada di lapangan } \\
\text { Adek Asuh teridentifikasi jelas, sehingga memudahkan } \\
\text { solusi yang terbaik untuk adek damping. }\end{array}$ & Juni, Agustus 2019 \\
\hline $\begin{array}{l}\text { Pendampingan } \\
\text { Pengurusan } \\
\text { administrasi sekolah } \\
\text { adek asuh di tahun } \\
\text { ajaran baru }\end{array}$ & $\begin{array}{l}\text { 1.Terbangunnya komunikasi antara pihak sekolah, } \\
\text { kakak damping, LAZ, Dinsos, dan UMS. } \\
\text { 2.Terselesaikannya permasalahan administrasi } \\
\text { sekolah adek asuh }\end{array}$ & Juni 2019 \\
$\begin{array}{l}\text { Pemberian Bantuan } \\
\text { Sarana Prasarana } \\
\text { Adek Asuh Pendidikan }\end{array}$ & $\begin{array}{l}\text { 1.Teratasinya permasalahan pendidikan terkait } \\
\text { pemenuhan kebutuhan Sarpras adek asuh } \\
\text { 2.Adek damping lebih termotivasi untuk bersekolah }\end{array}$ & Juli 2019 \\
\hline $\begin{array}{l}\text { Pembuatan Film } \\
\text { Dokumenter CSR utk } \\
\text { KKN Expo }\end{array}$ & $\begin{array}{l}\text { 1.Adanya dokumentasi kegiatan CSR UMS } \\
\text { 2.Mengkomunikasikan/menginformasikan kegiatan } \\
\text { CSR kepada masyarakat }\end{array}$ & Agustus 2019 \\
\hline
\end{tabular}

memiliki program yang berbeda, namun memiliki muara tujuan yang sama, yakni agar adik asuh memiliki semangat untuk terus bersekolah dan berkarakter baik. Dalam program ini, tim CSR dari universitas Muhammadiyah Surabaya (UM Surabaya) memiliki berbagai program yang mulai dilaksanakan di bulan Mei. Proses awal sosialisasi program ini telah berjalan di bulan Maret 2019. 
Aristiana Prihatining Rahayu, Agoes Poerwanto, Ngatmain/Aksiologiya: Jurnal Pengabdian Kepada Masyarakat. Vol. 5, No. 4, November 2021 Hal 538- 548

\begin{tabular}{|l|l|l|}
\hline & $\begin{array}{l}\text { 3.Memberi motivasi untk peduli kepada sesama } \\
\text { yang membutuhkan }\end{array}$ & \\
\hline Kelas Inspiratif & $\begin{array}{l}\text { 1.Melahirkan motivasi dalam diri adek asuh untuk } \\
\text { bersungguh-sungguh meraih cita-cita. } \\
\text { 2.Munculnya gambaran tentang cita-cita pada adek } \\
\text { asuh }\end{array}$ & Oktober 2019 \\
\hline $\begin{array}{l}\text { Membuat Buku dan } \\
\text { Video CSR 2018 } \\
\text { Portofolio Kegiatan) }\end{array}$ & $\begin{array}{l}\text { 1.Adanya dokumentasi kegiatan CSR 2018 } \\
\text { 2.Untuk mengkomunikasikan kegiatan CSR pada } \\
\text { 3.Sebagai media inspirasi dan motivasi bagi } \\
\text { masyarakat }\end{array}$ & Januari -Februari 2020 \\
\hline
\end{tabular}

METODE PENELITIAN

Program Campus Social Respinsibility (CSR) yang dimulai dari proses sosialisasi yang dilakukan oleh Dinas Sosial Kota Surabaya di bulan Maret ke beberapa kampus (roadshow) yang menjadi mitra program ini. Ada kurang lebih 24 kampus dari perguruan tinggi negeri maupun swasta di Surabaya yang terlibat dalam program sosial ini. Tahap berikutnya, perguruan tinggi melakukan perekrutan mahasiswa dari berbagai fakultas yang ada di perguruan tinggi. Di Universitas Muhammadiyah Surabaya, mahasiswa yang tergabung dalam program CSR berasal dari 3 fakultas_FKIP, Fakultas Ekonomis dan Bisnis, dan Fakultas Psikologi.

Alur proses pelaksanaan program CSR bisa di lihat pada gambar dibawah ini :

\section{SOSIALISASI PROGRAM DARI DINAS SOSIAL}

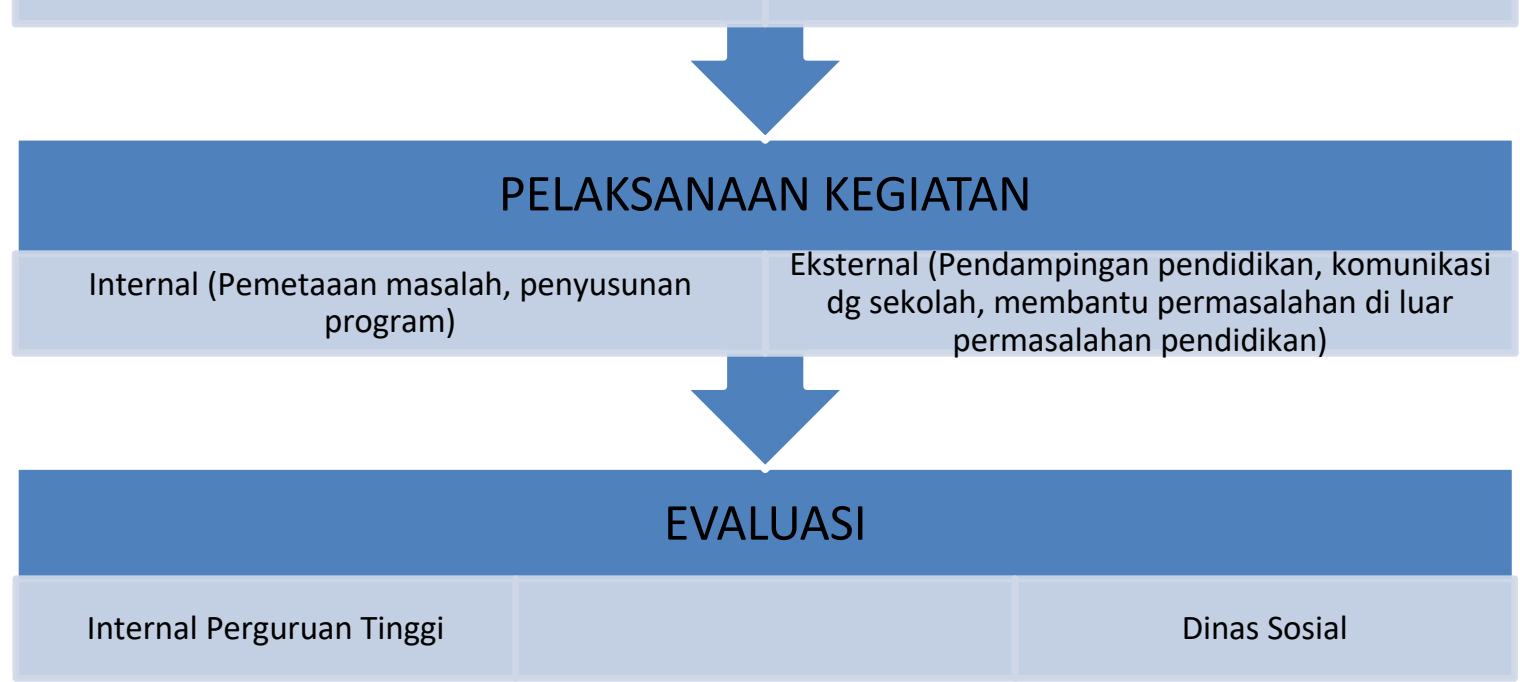

Gambar 1. Alur pelaksanaan program CSR 
Selain melibatkan perguruan tinggi, program CSR ini juga melibatkan media massa, lembaga swadaya masyarakat (LSM), satuan kerja pemerinta daerah (SKPD) kota
Surabaya, elemen masyarakat, dan relawan satuan tugas (satgas) dinas sosial Kota Surabaya.

Hubungan masing-masing elemen, bisa dilihat dalam gambar berikut :

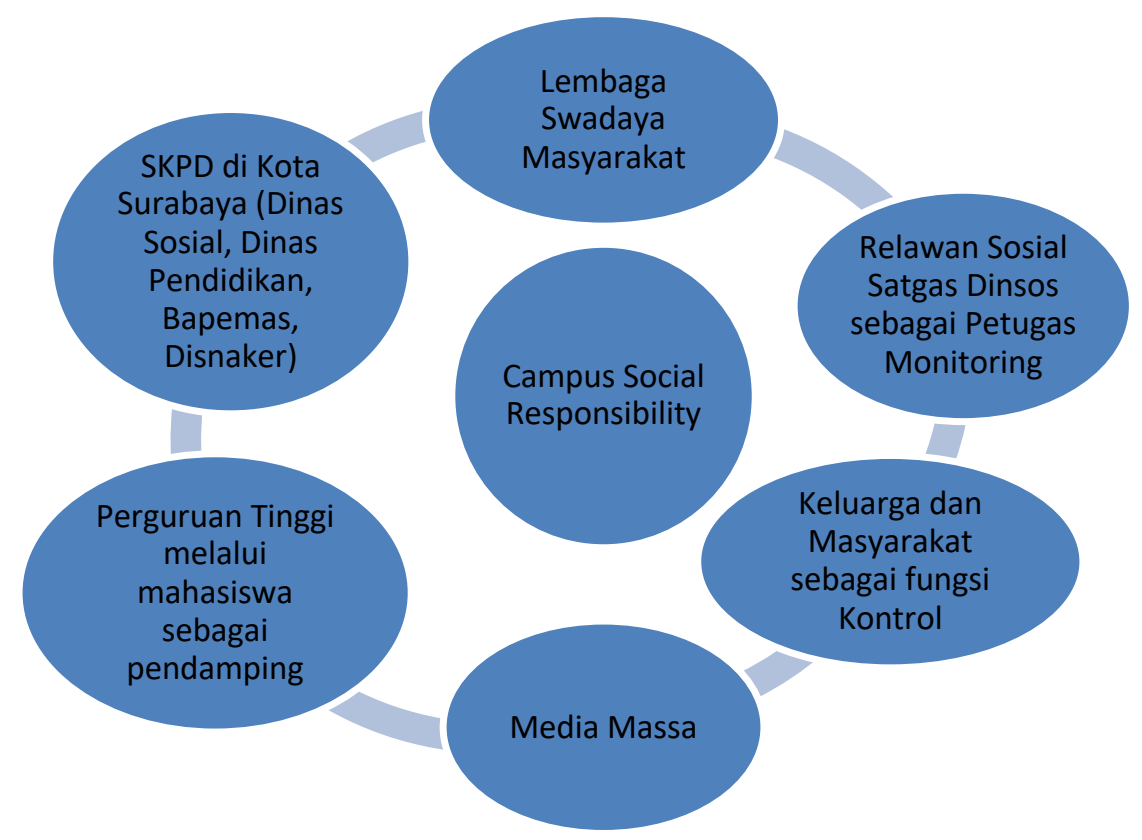

Gambar 2. Hubungan antar elemen yang terlibat dalam program CSR

Setiap elemen yang terlibat dalam program CSR saling menopang keberadaannya satu dengan yang lainnya. Misalnya, keterlibatan media massa dalam program campus sosial responsibility ini diperlukan untuk menginfokan pelaksanaan program CSR ke masyarakat. SKPD pemerintah kota Surabaya sebagai pemilik data adik asuh serta partner dalam pengambilan kebijakan yang terkait permasalahan adik damping.

\section{PEMBAHASAN}

Di awal pelaksanaan CSR di Universitas Muhammadiyah Surabaya, dosen pendamping lapangan (DPL) melakukan koordinasi dengan 35 mahasiswa yang tergabung dalam tim CSR 2019, terkait upaya pemetaan persoalan adik damping masing-masing mahasiswa. Setiap kampus, selain memiliki dosen pendamping lapangan, serta satu mahasiswa yang ditunjuk sebagai koordinatur kampus (korpus). Pemetaaan persoalan ini dilakukan setelah mahasiswa bertemu dengan adik damping masing-masing yang telah ditentukan oleh dinas sosial. Dalam pemetaan persoalan tersebut, dilakukan pengelompokan permasalahan yang dialami oleh adik damping mahasiswa. 
Dalam

pemetaan

permasalahan, ditemukan bahwa permasalahan ekonomi (kemiskinan) pada keluarga adik damping, telah melahirkan berbagai persoalan yang menyebabkan terganggungnya proses pendidikan. Akibatnya, sebagian adik damping memiliki tunggakan pembayaran sekolah, mengalami bullying, tidak diterima dalam pergaulan sosial, kesulitan memenuhi kebutuhan sarana prasarana sekolah (sepatu, buku, tas, sepeda sebagai sarana transportasi, seragam, dsb). Selain faktor kemiskinan, permasalahan lain yang ditemukan adalah kurang harmonisnya huungan antar anggota keluarga, orang tua sering berkonflik karena permasalahan ekonomi, kepala keluarga sakit, atau tidak memiliki pekerjaan tetap. Rendahnya perhatian serta motivasi orang tua pada anak (adik damping) juga berpengaruh dalam kelangsungan pendidikan.

Hal lain adalah, salah pergaulan. Lingkungan pergaulan yang tidak kondusif, menyebabkan adik damping sering membolos, terlibat kelompok gank, dan melakukan berbagai penyimpangan perilaku lainnya, yang berdampak pada kelangsungan sekolahnya. Selain itu, hubungan yang kurang harmonis antara orang tua dan pihak sekolah, juga memiliki kontribusi anak-anak dari keluarga penyandang masalah kesejahteraan sosial (PMKS) ini, rawan atau bahkan putus sekolah. Tidak adanya sarana transportasi seperti sepeda untuk pergi ke sekolah, juga menjadi persoalan bagi sebagian adik damping yang rumahnya jauh dari sekolah. Ketidakmampuan maupun keterbatasan orang tua untuk memberi uang transport, seringkali menyebabkan adik damping sering tidak masuk sekolah atau terlambat datang ke sekolah.

Berdasarkan hasil pemetaan permasalahan, kemudian dibuat berbagai program yang diharapkan mampu memberikan solusi dalam penanganan persoalan adik damping sesuai dengan kapasitas yang dimiliki mahasiswa. Beberapa program pokok tersebut adalah pendampingan belajar pada adik damping, mencarikan serta mendaftarkan sekolah adik damping saat tahun ajaran baru bagi mereka yang putus sekolah maupun yang melanjutkan pendidikan ke sekolah yang lebih tinggi. Program lainnya adalah membantu memperbaiki komunikasi atau hubungan baik antara orang tua adik damping dan pihak sekolah, mencarikan donatur bagi adik yang membutuhkan support pembiayaan sekolah, sedekah buku, kelas inspiratif dan morning call.

Program pendampingan mahasiswa dalam program campus sosial responsibility ini bisa dikatakan berhasil untuk membantu menekan angka putus sekolah anak di Surabaya. Ika Setyawati_mahasiswa fakultas psikologi universitas Muhammadiyah Surabaya, adalah salah satu contoh mahasiswa yang sukses mengembalikan adik dampingnya kembali ke sekolah. Sebelumnya, adik damping 
mengalami putus sekolah. Beberapa faktor yang menyebabkan adik damping tidak lagi mau bersekolah adalah karena mengalami bullying di sekolah. Selain itu, hubungan keluarga yang kurang harmonis antara ibu, ayah, nenek dan kakeknya menyebabkan adik damping mengalami tekanan secara psikologis. Hubungan keluarga yang tidak harmonis tersebut, salah satunya dipicu karena kondisi ekonomi keluarga yang kekurangan dan sang ayah sebagai kepala keluarga, tidak memiliki pekerjaan tetap. Berbagai permasalahan yang bertumpuk tersebut dan kurangnya perhatian orang tua pada kondisi adik damping, menyebabkan adik damping tidak mau lagi melanjutkan sekolah, dan memilih bergaul dengan remaja yang tergabung dalam genk motor.

Setelah melakukan pemetaan masalah, mahasiswa ini kemudian mulai menyusun langkah-langkah strategis yang dilakukan selama pendampingan untulk bisa mengembalikan adik damping ke sekolah. Hal yang dilakukan pertama kali adalah berkomunikasi dengan keluarga untuk mencari informasi lebih detail tentang permasalahan dan kondisi yang dialami adik damping. Seiring proses komunikasi dengan keluarga, mahasiswa juga melakukan pendekatan secara psikologis kepada adik damping. Hubungan yang komunikasi yang baik antara mahasiswa dengan adik damping serta keluarganya, menyebabkan adik damping mau untuk kembali bersekolah. Dan di tahun ajaran baru, mahasiswa melakukan upaya untuk mencarikan Sekolah Menengah Negeri bagi adik dampingnya_dari mulai proses mencari informasi ke dinas pendidikan kota Surabaya, pendaftaran, hingga berkomunikasi dengan pihak sekolah adik damping.

Kisah sukses mahasiswa yang mampu memberikan motivasi dan pendampingan pada adik dalam program CSR juga dilakukan mahasiswa dari fakultas keguruan dan ilmu pendidikan (FKIP) universitas Muhammadiyah Surabaya, Alvira Alamanda. Mahasiswa ini berhasil memotivasi dan mendampingi adik dampingnya sehingga berhasil meraih juara 2 tingkat nasional kejuaraan Tapak Suci. Adik damping, pada awalnya adalah anak yang pemalu dan kurang percaya diri. Namun berkat pendampingan mahasiswa serta support dari ibu (single parent), adik damping kembali termotivasi untuk terus bersekolah dan mengasah prestasi di bidang non akademik. Selain memberikan motivasi pada adik damping, mahasiswa juga membantu mengupayakan pembiyaan adik damping, saat mengikuti kejuaraan tapak suci tingkat nasional. Mahasiswa juga berhasil mengupayakan bantuan sepeda untuk transportasi adik damping. 
Aristiana Prihatining Rahayu, Agoes Poerwanto, Ngatmain/Aksiologiya: Jurnal Pengabdian Kepada Masyarakat. Vol. 5, No. 4, November 2021 Hal 538-548

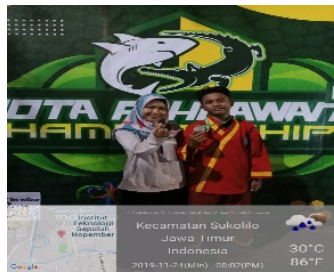

1

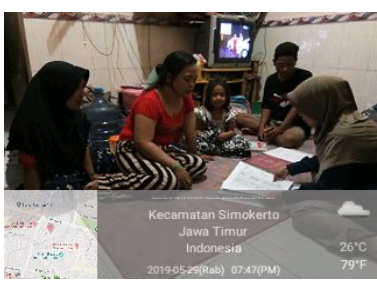

3

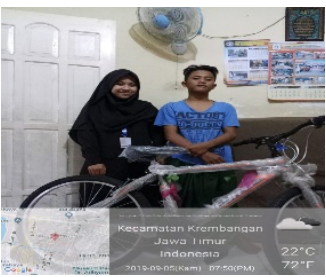

2

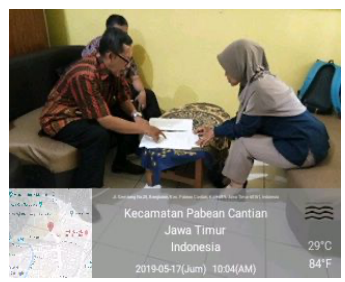

4

Gambar 2. 1. Mahasiswa mendampingi adik damping yang mendapatkan juara 2 Tapak Suci tingkat nasional. 2. Bantuan sepeda untuk adik damping, 3. Mahasiswa melakukan komunikasi dengan keluarga adik damping. 4. Mahasiswa membantu pengurusan sekolah/pendidikan adik damping.

Selain melakukan berbagai program pendampingan pendidikan dan bantuan sosial kepada adik damping, tim CSR universitas Muhammadiyah Surabaya juga membuat karya dokumentasi berbentuk video. Karya yang berupa video, telah diunggah di kanal youtube. Dua diantaranya ada pada gambar 3

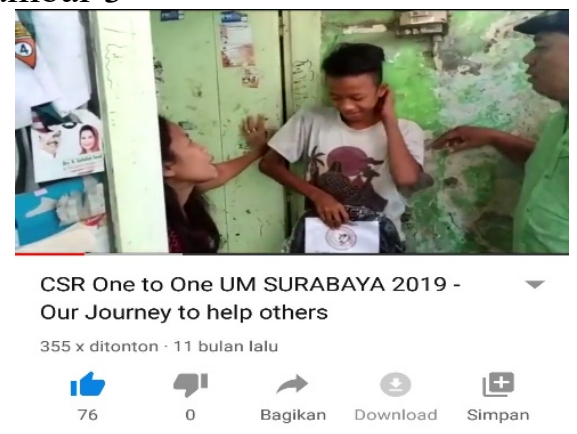

Gambar 3. Dokumentasi kegiatan program CSR one to one di kanal Youtube

a.https://www.youtube.com/watch? $v=x g$ X1-ADXQfY

b.https://www.youtube.com/watch? $v=\mathrm{R}$ $\underline{1 \mathrm{C} 1 \mathrm{NmjPxwU}}$

Pembuatan

video

dokumentasi CSR bertujuan untuk memberikan motivasi kepada adik damping melalui pesan-pesan tokoh/selebriti, sebagai upaya mengkomunikasikan program CSR ini kepada masyarakat. Tujuan yang lebih utama adalah membangun solidaritas kepada sesama yang membutuhkan uluran tangan.

\section{KESIMPULAN}

Kegiatan campus social responsibility (CSR) one to one telah terbukti mampu menjadi bagian solusi bagi penanganan anak-anak yang rawan maupun putus sekolah di kota Surabaya. Program ini juga mampu membangun jiwa sosial serta kesadaran mahasiswa akan pentingnya untuk peduli kepada sesama yang membutuhkan.

\section{DAFTAR PUSTAKA}

Harlock, Elizabeth B.2002. Suatu Pendekatan Sepanjang Rentang Kehidupan. Jakarta: Pernebit Erlangga

Huraerah, Abu. 2006. Kekerasan Terhadap Anak : Fenomena Masalah Spsial Kritis di Indonesia. Bandung: Penerbit Nuansa.

Hariadi, Sri Sanituti \& Bagong Suyanto (eds.). 2001. Anak-Anak yang Dilanggar Haknya: Potret Sosial Anak Rawan di Indonesia yang Membutuhkan Perlindungan Khusus. Kerjasama Pusat Kajian UNAIR, LPA Jatim, dan UNICEF. 
Aristiana Prihatining Rahayu, Agoes Poerwanto, Ngatmain/Aksiologiya: Jurnal Pengabdian Kepada Masyarakat. Vol. 5, No. 4, November 2021 Hal 538-548

Irwanto, Muhammadf Farid \&Jefrri Anwar.199. Anak yang Membutuhkan Perlindungan Khusus di Indonesia: Analisis Situasi. Jakarta : Kerjasama PKPM Unika Atmajaya Jakarta, Departemen Sosial dan Unicef.

Kuntoro dkk. 1996. Beberapa Faktor yang Mempengaruhi Putus Sekolah Siswa Wanita di Sekolah Dasar dan Lanjutan Tingkat Pertama di Beberapa Desa di Jawa Timur.
Kerjasama BKKBN, UNFPA, dan pusat Penelitian Kependudukan dan Pembangunan Lembaga Penelitian Universitas Airlangga.

Suyanto, Bagong 2010. Masalah Sosial Anak. Jakarta: PRENADAMEDIA GROUP, 2010

Suyanto, Bagong.dkk (eds).2000. Tindak Kekerasan Terhadap Anak : Maslah dan Pemantauannya. Surabaya: Kerjasama LPA Jatim dan UNICEF. 